v. 8, n.3

Vitória-ES, Jul. - Sep. 2011.

p. $01-19 \quad$ ISSN 1808-2386 DOI: http://dx.doi.org/10.15728/bbr.2011.8.3.1

\title{
Logistical performance: impact of the use of a logistical tool of self-assessment by first tier suppliers of the automotive industry
}

\author{
Alexandre Reis Graeml ${ }^{\dagger}$ \\ Positivo University (UP) \\ Jurandir Peinado ${ }^{\Omega}$ \\ Positivo University (UP) \\ Marco Aurélio Kurrle ${ }^{\ddagger}$ \\ Positivo University (UP) \\ João Alberto Schaicoski ${ }^{\mathfrak{E}}$ \\ Positivo University (UP)
}

SUMMARY: This paper evaluates the perception of an automotive company assembling commercial transport vehicles and its suppliers about the effectiveness of a tool implemented for the assessment of logistical performance (MMOG/LE). At a preliminary stage of the research, the perception of suppliers had been captured through a survey in which 28 companies participated. Unstructured interviews were conducted with two professionals from the automotive company's logistics area, after they became aware of the results of the research with the suppliers, to get these professionals' opinion about the implementation of MMOG/LE at the company's main direct suppliers. The automotive company also gave access to internal documentation tracking the suppliers' performance, when these suppliers provided objective evidence that the logistical performance has been constantly improving, which is attributed, at least in part, to the utilization of the assessment tool by the company and by its suppliers.

Keywords: MMOG/LE; logistical; evaluation.

Author's correspondence*:

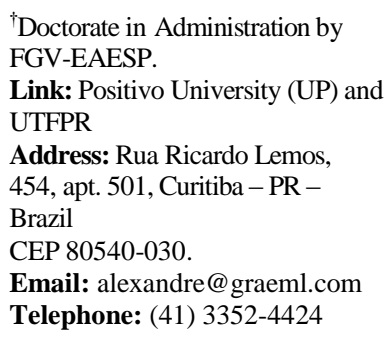

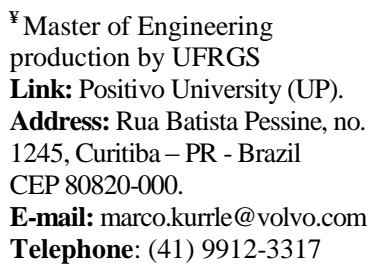

\author{
${ }^{£}$ Logistics Specialist \\ by the Positivo University (UP) \\ Link: Positivo University (UP). \\ Address: Travessa Rafael \\ Francisco Greca 120, ap 201, \\ Água Verde, Curitiba - PR - \\ Brazil - CEP 80620- 150 \\ Email: joao.schaicoski@cnh.com \\ Telephone: (41) 2107-7722
}

Editor's Note: This paper was accepted by Antonio Lopo Martinez. 


\section{INTRODUCTION}

Changes in the business environment in recent decades have demanded the replacement of finance-based business management based on productivity with a new model based on competitiveness, which is summarized in the organization's ability to differentiate itself from competitors and to operate at a low cost (BOWERSOX et al., 2006). According to Ballou (2006), the traditional ways to improve productivity, quality and costs were no longer seen as effective. In this scenario, logistics appears as a new opportunity to make gains. This explains why it has been called the "last competitive frontier." (TABOADA, 2002) "Logistics has been showing a steady evolution and is now a key element in the companies' competitive strategy ", states (COURÁ, 2002 , p. 12). In the past, it was closely related to the areas of transportation and product storage. But today, "it is a fundamental factor in the integrated supply chain, working in close harmony with the modern supply chain management." (COURÁ, 2002, p. 12). The reason for the attention paid to logistics processes having increased is associated with the fact that companies have realized that they no longer held their position just by reducing their internal costs. Part of the effort to increase efficiency involves the coordination of activities with suppliers and customers (HARRINGTON, 2005), which makes companies in different industries look to better manage these inter-business relationships.

$\mathrm{Li}$ and Kumar (2005) argue that the business environment today is characterized by two main factors: (1) intense global competition that forces companies to seek continuous cost reductions and new opportunities; (2) management of the supply chain, which has become a way to add value to the product and increase the company's competitive advantage.

According to Parry et al. (2006), the group of suppliers to companies has been streamlined and now a few "chosen ones" are part of this select group, being in direct contact with customers that demand more attention and great responsibility. The development of closer relationships and the exchange of proprietary information have become a priority with these companies.

Logistics and supply chain management are gaining recognition in companies throughout the world, conclude Mollenkopf and Dapiran (2005) in a study that brings together a large number of companies in Australia and New Zealand. The importance of this work stems from the geographical location of these countries, which requires special logistics competence. When it comes to interacting with global markets it is necessary to use techniques that allow logistics to create some kind of competitive advantage. 
After analyzing several papers on the issue, such as those written by Guisi and Silva (2006), Marujo (2006) and Figueiredo et al. (2007), for example, one realizes that the race for differentiation in the logistical arrangements in recent years has increased the level of detail to which logistical issues have been submitted, which begins to demand the creation of shared metrics for evaluating the actual effectiveness of actions taken by companies to ensure delivery of their product to the customer at the right time, in the amount requested, with the expected quality and without hindrance.

Although logistics has assumed a prominent position among the business activities in recent years, due to efforts allowing relatively smaller efforts to yield more significant results than those promised by changes in other areas, assessment tools that help measure the effectiveness of logistics performance (BALLOU, 2006).

The research reported in this paper intended to evaluate the perception of the effectiveness of an assessment tool of logistical processes by an assembler of commercial transport vehicles and its major suppliers. It is about the MMOG/LE recommendation (Materials Management Operations Guideline/Logistics Evaluation), which is further discussed in this paper. More specifically, we sought to identify the actual contribution of MMOG/LE to improve performance with respect to the following aspects, which represent the intentions of its proponents: business strategy, organization of work, capacity and production planning, improvement of the interface with customers, product and production control and improvement of the interface with suppliers.

The development of the research was justified, from a practical point of view, by the possibility of disclosure of this tool's potential to other industrial organizations if its effectiveness became apparent. In the case of a readily available model (accessible from the Websites of the proponent organizations and of low cost implementation) consisting of an evaluation form in an Excel file, the MMOG/LE can be useful, if its effectiveness can be proven to provide the standardization of expectations about the logistics performance along the supply chains of the entire industrial sector. The fact that the research result might not be favorable to the MMOG/LE tool also would also represent an important finding, meaning that it needs to be improved and made more useful to its users or replaced by another more appropriate tool.

From a theoretical perspective, the research also was easily justified by the observation that, although the logistics and management of supply chains were in evidence, both in academics and in business practice, as already mentioned, there are few studies dealing with the assessment of its performance, something essential to enable improvements. After all, you cannot manage what you cannot measure ${ }^{1}$. 
It is noteworthy that this study did not intend to evaluate the quality of logistic management practiced by the participating organizations. It was only intended to identify their perceptions about the suitability and effectiveness of the MMOG/LE recommendation as a tool for (self-) evaluation and improvement.

In the following sections, after this brief introduction, the need to measure the performance of logistics procedures will be discussed, with the presentation of the MMOG/LE tool as the next step. Then the methodology used in collecting and analyzing data is discussed, followed by its presentation and discussion. The article ends with conclusions and final considerations, including possible referral to future studies and the discussion of limitations of the present one.

\section{THE NEED TO MEASURE PERFORMANCE OFLOGISTICAL PROCEDURES}

Through the current awareness of the importance of logistics processes in organizations, forms and systems dedicated to the measurement and evaluation of logistics performance are becoming topics of discussion. Hijjar, Gervásio and Figueiredo (2005) analyze the World Class Logistics model, pointing out that a good system of performance monitoring is critical to managing logistical activities. They further argue that performance measurement is essential to verify that the objectives set by the company are being met, assisting in the effective application of resources allocated to logistics. To these authors, the monitoring of logistics processes "is even more important in the current scenario in which the activities related to logistics are being recognized worldwide as highly important for generating customer value” (HIJJAR, GERVÁSIO and FIGUEIREDO, 2005, p. 1).

New tools for assessing logistics are being created and also applied for the providers of contract logistics services (3PL). Yan et al. (2003) present an assessment methodology of logistics performance geared specifically to measure the quality of services provided by these companies, which is perfectly justified due to the growing demand for outsourced services. The methodology was called CBR (case-based reasoning). According to its proponents, CBR is a type of decision model for solving problems in the choice of service provider by the contracting company. The method uses adaptations of lessons learned from similar experiences in the past to assist in proposing the best alternative at the present. The measurement system for the decision of choice for logistics operators is set up based on four factors:

1. information from the environment in which the company operates;

2. information about the services provided in the past by the company; 
3. technical and financial information and administrative conditions of the company being evaluated;

4. relative importance of each type of information. According to empirical research conducted by Yan et al. (2003), the method proved to be applicable in practice.

Martins and Gonçalves (2004) discuss the effectiveness of a system of performance indicators consisting of technical and commercial aspects, aiming at better understanding the relationship between automakers and the supply chain. Thus, they anticipate that the discussion has intensified in the years that followed, leading several automakers in Europe and North America to merge their standards and assessment requirements of logistics performance, based on initiatives of groups of companies in the automotive sector on both continents (Odette and AIAG, respectively), who developed the MMOG/LE recommendation, as explained below, in "The MMOG/LE Recommendation".

Jawab and Bouami (2007) argue that to properly manage the company's logistics performance, audits and diagnoses are needed, involving a discussion on how these two procedures complement each other and noting that the audit is an operation designed to verify compliance in relation to a standard, while the diagnosis is intended to verify the value, relevance and coherence of what is done. The diagnosis therefore has a strategic dimension, being able to determine or be accompanied by a change in the company's priorities, structures and culture. The ISO 10011 standard defines logistics auditing as a methodical and independent examination to determine whether the activities and results related to logistics meet pre-established rules, whether those provisions are properly followed and if they allow meeting the defined objectives.

According to Zoller (2006) the performance of availability (in- stock performance) is a leading indicator of industrial competitiveness. However, it is necessary that the investment in inventories be rational. For example, a supplier must consider the considerable impact of a lack inventory to determine the value of safety stocks needed. The focus is on serving the customer well with the lowest possible inventory.

Ha, Li and NG (2003), based on a study involving several companies in Hong Kong, said that when two suppliers compete for the same customer, price and delivery frequency are the key decision factors. According to the authors, it is not enough to provide the lowest cost; frequency, speed and accuracy of deliveries are essential as sources of competitive advantage. Delivery precision is calculated as the rate: number of correct deliveries / total number of deliveries in a specific period of time. Correct deliveries are those that happened at the correct date and consisted 
on the correct amount, according to the customer's purchase order. As the cost structure rarely changes significantly from one supplier to another, the checking and the control of the accuracy of delivery have become common practice at the customer premises. Handfield and Pannesi (1992) also highlight that the competitive advantage of delivery involves two decision criteria: speed and reliability. Improving the speed of delivery is achieved by improving production processes, which may be internal or external to the company. On the other hand the improvement of reliability (or accuracy of delivery) depends almost exclusively on the organization of activities within the company.

\section{THE MMOG/LE RECOMMENDATION}

MMOG/LE involves a set of practices and procedures related to materials management and logistics created by members of the industry (HARRINGTON, 2005), which can be used in various industrial sectors.

The MMOG/LE document consists of an Excel file containing questions about business practices and logistics management procedures. According to the document itself, its use provides three important outputs (AIAG, 2006):

- self-assessment: MMOG/LE guides and allows the conduction of an internal audit of the internal management of logistics procedures, performed by the company itself, without the intervention of other parties;

- measurement: the self -assessment conducted by MMOG/LE allows scoring on a scale of zero to one hundred points to the logistics performance of the organization, whose standardization provides an important tool for benchmarking; and

- plan for improvements: the self-assessment promotes the identification of the areas that need improvement, called gaps, which can be used to guide the deployment of plans for continuous improvement within the company, or as a tool for development of suppliers.

Companies that provide components to several automakers at the same time struggled to prove the quality of its logistical arrangements, because each manufacturer had different requirements, although with the same purpose, depending on the different norms utilized ${ }^{2}$. Therefore, AIAG and Odette, the two organizations that bring together companies in the automotive sector in North America and Europe, respectively, worked together to create a logistics assessment document that could be used globally in the sector (AIAG, 2006). The importance of the unification of the various logistics assessment procedures for the automotive industry is highlighted by Witt (2005, p. 20), which states that "all global supply chains have 
essentially the same activities: receiving, storing, shipping and transporting". The problem is that, prior to MMOG/LE, "these supply chains spoke different languages."

Thus, the MMOG/LE recommendation can serve two important specific demands of the automotive industry: (1) the need to define a criterion for assessment of logistics performance and (2) the need to unify the many different standards and recommendations of all types, required from the suppliers of the large automakers (GUSTAFSSON and PERSSON, 2007; HARRINGTON, 2005; INTERNET AUTOGUIDE, 2004). Its main purpose is therefore to provide a common assessment guide of material planning and logistics, which can be used both by suppliers and bythe automakers.

Witt (2005) considers that the logistics assessment provided by the MMOG/LE recommendation translates the terminology of materials management and outlines its processes so that everyone can understand its meaning. Thus, the recommendation serves as a referential, providing an evaluation system consists of questions that need to be examined for a possible diagnosis of the organization's logistics competence.

According to Jawab and Bouami (2007), references are an indispensable basis for comparison indispensable to the evaluation's composition. These authors highlight the importance of the MMOG/LE recommendation, among the many existing frameworks for evaluating logistics, because it is a world standard, to which many automakers have joined.

According to Quality Progress (2004) magazine, the MMOG/LE recommendation was developed with the aim of reducing the time and effort required from suppliers and from customers to assess their logistics processes, which impact on the cost, on turnaround and on the physical inventory of materials and products.

One of the main indicators of logistics performance is precision of delivery. In this regard, Gustafsson and Persson (2007) consider that the MMOG/LE recommendation brought significant progress to the area of materials management, promoting the balance between production and demand. They note that the major suppliers of the automakers argue that the precision of delivery indicator should be perfect and impose penalties on providers who are unable to achieve it.

Some surveys conducted by members of the automobile industry itself with suppliers of the automotive industry who have recently adopted the MMOG/LE recommendation describe the methodology as more user-friendly and emphasizes the adoption of better logistics practices, directing the performance to what is expected from a world-class provider (ONICA, 2006). This 
is what was this study intended to demonstrate, whereby the methodological procedures described below were adopted.

\section{METHODOLOGICAL PROCEDURES}

As already mentioned, the general objective of this research was to evaluate the perceived effectiveness of an assessment tool of logistic processes of supply chain by an automotive company assembling commercial transportation vehicles and its main suppliers.

To assist in achieving this primary objective, some secondary goals were established:

- to understand the perceptions of suppliers on the contribution of MMOG/LE to improve their own logistics process;

- to understand the perception of the automaker about the contribution of MMOG/LE in the improvement of its suppliers' performance;

- to assess whether there is an alignment between the perceptions of suppliers and the automaker's on the contribution of MMOG/LE for the improvement of the logistics performance of the supply chain.

The methodological procedures to achieve the following objectives were the following:

- use of a questionnaire to collect information on the perceived effectiveness of the MMOG/LE recommendation to improve the automaker's suppliers' own logistics performance (that had already been accomplished in a previous step of the research project, whose results are reported here by way of allowing its discussion together with the results of interviews with professionals from the automaker);

- analysis of documentation provided by the automaker on the logistics performance of its suppliers;

- interviews with those responsible for the materials logistics area of the automaker to get their perception of the effectiveness of the MMOG/LE recommendation to improve logistics performance of its suppliers;

- comparison of the main issues highlighted by the suppliers and by the automaker on the effectiveness of the MMOG/LE recommendation as an evaluation tool and indicating potential improvements in the business's logistics.

The study on the perceptions of suppliers was held in February 2008, with collection of data through a structured questionnaire containing questions on a Likert scale. Twenty statements were laid down in the questionnaire, about which the suppliers should indicate their level or 
agreement which could be one of the following: "fully agree", "agree", "no opinion", "disagree", "totally disagree". All the statements handled the importance of the MMOG/LE recommendation to improve logistics performance in some activity considered key for the accuracy of delivery a factor deemed as essential by the automaker to guarantee the supply chain's effectiveness. These statements will not be individually presented and discussed here, since the intention is to only identify the respondents' perception about the tool's contribution to improve logistics performance in a general way.

The survey was sent through email to executives in charge of, or very experienced in, the logistics area, who had participated in a training program about the implantation of the MMOG/LE recommendation, totaling 108 direct suppliers of the truck assembler.

Approximately 25 of the e-mails sent were wrong, which reduced the possible answerers to 83 . Of those, 28 answered the request, resulting in a return rate of approximately $30 \%$. The existence of a certain link between participants and researchers, since the former had been trained by the latter in the MMOG/LE recommendation may have helped to a higher return rate than the usual one in electronic surveys. Vieira, Viana and Echeveste (1998), Scornavacca Jr., Becker and Andraschko (2001), Cohen (2003), Graeml and Csillag (2006), just to mention some researchers who adopted this instrument of data collection, worked with return rates considerably lower in their research, in spite of having used e-surveys earlier on, when people were still not so "bombarded" by surveys over the web.

The fact that the achieved sample is not random, as it resulted from the participants decision to fill in the survey, and considering that other more reliable sample representativeness tests were not feasible, could be considered a limitation of the study, as no inferences are possible to the population, without incurring in a risk of misrepresentation. However, the sample did not differ much from the population with respect to the demographic characteristics that could be assessed (size and location). Further analyses of possible differences among respondents and nonrespondents were not carried out because, as the respondents did not identify themselves in the survey, it was not possible to isolate a group of known non-respondents to check their reasons for not participating. In spite of that, the authors have no reasons to believe that there are relevant differences among respondents and non respondents with respect to their perception about the MMOG/LE recommendation.

The questionnaire items were designed to allow the identification of the perceived level of contribution of MMOG/LE for the improvement of the logistics processes. To this end, the questions were about some of the critical processes related to logistics operations, according to the 
MMOG/LE recommendation itself, called $\mathrm{F}^{3}$ processes, i.e., those which, if not treated properly, cause a high risk of disruption to customer operations, with the possibility of additional costs in the short term (ODETTE and AIAG, 2006).

The documents accompanying the logistics performance of suppliers made available by the automaker were analyzed during the month of March 2008, which was followed by interviews with business professionals held in April, that year.

There was an intention to extract from the interviews indications on whether the company as a supporter of the adoption of the self -assessment of logistics processes by its providers, believes that the MMOG/LE is delivering the planned results. The discussion with its professionals also covered the improvements of the suppliers' logistics performance, observed by the analysis of the documentation, trying to verify how strongly this is related to the implementation of logistics assessment through the use of the MMOG/LEtool.

\section{RESULTS}

Data collected from the questionnaire ended up representing a rich source of information on which a second round of interviews with professionals from the automaker could be based. Because of space limitations, this paper will only show the most relevant results obtained from the tabulation of the questionnaires, which were confirmed or which conflicted with the perceptions and documentary evidence presented by the automaker.

Out of the 28 participants who answered the questionnaire (automaker's supplier), 4 stated that they had yet implemented the MMOG/LE recommendation in their companies, although they intended to do so briefly. Among the other 24 companies, the implementation took place 15.9 months, on average, prior to the survey, with great variance: the one who adopted the recommendation most recently did so 2 months before, while the one who has been using the recommendation the longest, started its implementation 36 months before.

By tallying the answers and assigning a ranking score in a 5-point scale varying from one point to the "fully agree" answer up to five to the "totally disagree" answer, it was possible to arrive at an average by all respondents related to each one of the statements. Chart 1 shows the results. Chart 1 shows the obtained results. Note that the questions for which the average is above 3 show that the respondents tend to agree with the statement, while those with averages below 3 reflect a disagreement trend. Although there is no normal distribution for the responses (which would be impossible, considering that a Likert scale was used), the size of the sample was large 
enough for $t$ statistics to be used in order to find a confidence interval for the average of the responses for the population, based on the sample data.

\begin{tabular}{|c|c|c|c|c|c|c|c|c|c|c|}
\hline Question & $\mathbf{1}$ & $\mathbf{2}$ & $\mathbf{3}$ & $\mathbf{4}$ & $\mathbf{5}$ & $\mathbf{6}$ & $\mathbf{7}$ & $\mathbf{8}$ & $\mathbf{9}$ & $\mathbf{1 0}$ \\
\hline Average & 1.9 & 1.9 & 2.0 & 1.7 & 2.1 & 1.9 & 2.1 & 2.0 & 2.1 & 1.9 \\
\hline S.D. & 0.5 & 0.7 & 1.0 & 0.5 & 0.9 & 0.4 & 1.0 & 1.0 & 0.6 & 0.3 \\
\hline Question & $\mathbf{1 1}$ & $\mathbf{1 2}$ & $\mathbf{1 3}$ & $\mathbf{1 4}$ & $\mathbf{1 5}$ & $\mathbf{1 6}$ & $\mathbf{1 7}$ & $\mathbf{1 8}$ & $\mathbf{1 9}$ & $\mathbf{2 0}$ \\
\hline Average & 2.2 & 2.2 & 2.1 & 2.0 & 2.2 & 2.1 & 2.6 & 2.1 & 2.0 & 2.0 \\
\hline S.D. & 1.0 & 1.1 & 1.1 & 1.0 & 0.9 & 1.2 & 1.6 & 0.6 & 0.7 & 0.7 \\
\hline
\end{tabular}

Chart 1 - Answers

Source: the authors

Note 1: the confidence interval was calculated for $\alpha=0,05$.

Note 2: note that only for question 17 the center of the scale (3.0) is inside the confidence interval, making it impossible for inferences to be made about the agreement or disagreement of the respondents with respect to it.

The analysis of the average and standard deviation of the results presented in Chart 1 points to the fact that most respondents "agree" with the various statements contained in the 20 questions. The average for all questions was very close to 2.0 and the standard deviation was generally low. Only three participants answered "disagree" to any question. In no case did anybody point the alternative "strongly disagree" out. This result shows that the participants consider that the MMOG/LE recommendation helps to improve the logistics performance.

Another important finding obtained from the questionnaire was that MMOG/LE is more useful in helping companies improve their performance in ways that were not directly demanded by quality standards, widely deployed in the automotive sector.

The importance of MMOG/LE in making companies realize the need to integrate electronically with suppliers was particularly evident, something not contemplated in the quality systems implemented by the companies. None of the respondents marked the alternative, the company was already very efficient in this item before MMOG/LE" to the questions that dealt with electronic integration among supply chain partners, something that happened on average in $20 \%$ of the cases, for most other issues. The respondents (automaker professionals confirmed the fact that the electronic integration, or rather the lack of it, is in fact a noise factor in communications between supplier and customer.

In the countless training sessions performed in Brazil on the MMOG/LE recommendation, all of them conducted or at least managed by the researchers involved in this study, the question of electronic integration with suppliers and clients was always considered the "Achilles heel" of the logistics systems implemented by the companies of the automotive sector. Even considering 
that this sector is technologically advanced, automation in the exchange of information is still a problem, mainly when the issue is the connection of the automakers' direct suppliers with their own suppliers and to the suppliers of their suppliers. As we travel upstream in the chain of supplies, the size of the companies becomes gradually smaller, hand in hand with resources for investment, or the automotive sector becomes less important as a client, and consequently its bargaining power in asking for efficiency in inter-company integration. If resources or interest are lacking, it becomes difficult to convince the suppliers to make heavy investments in IT, which oftentimes are necessary in this type of integration.

It should be noted that for the integration with clients, differently from integration with suppliers, there were participants stating that the company that "the company was already very efficient in this item before MMOG/LE". This apparent distortion (more worried about integration with the client than with the supplier) is that, in the case of the research participants, the client is an automaker, which certainly has exerted due pressure on a strong client to ensure the level of integration that would improve its knowledge about the capacity of its clients to meet its orders.

The analysis of documentary sources provided by the automaker on the performance of its logistics providers also appeared to be an important source of information. The documents show the records of indices of accuracy of delivery of over one hundred first-tier suppliers. Table 1 presents the status of these providers in relation to the adoption of the MMOG/LE recommendation, their classification (A, B or C level, depending on the quality assessment of the logistics processes in place) and to the way the rating was evaluated: self -assessment or audit by the automaker.

Suppliers classified as "self -assessment" in Table 1 provide the results of the evaluation that they themselves carried out, and have not been audited by the automaker. The suppliers in the "audit" column provided their results and were subsequently audited by the client. According to the respondents, the company promotes the audit when it detects a possibility that the supplier has committed a mistake in self-assessment submitted, by comparing the declared performance (measured from the MMOG/LE ) and the performance perceived by the automaker (obtained from historical records of delivery by the supplier). This demonstrates that the automaker believes that there is a strong correlation between positive self -evaluation, as long as carefully conducted, and performance in deliveries, which denotes that the company believes in the tools' effectiveness. 
Table 1 - Ranking of suppliers according to the logistics performance criteria of MMOG/LE

\begin{tabular}{lccc}
\hline Rank & Audit & Self-evaluation & Total \\
\hline Level A & $4.4 \%$ & $17.8 \%$ & $22.2 \%$ \\
Level B & $4.4 \%$ & $8.1 \%$ & $12.6 \%$ \\
Level C & $3.7 \%$ & $23.0 \%$ & $26.7 \%$ \\
Do not use MMOG/LE & - & - & $38.5 \%$ \\
\hline
\end{tabular}

Source: documentation from the automaker

Although the MMOG/LE recommendation is geared towards self-assessment and not to an audit by third parties, it "is objective in its questions, with little room for different interpretations by different people. Furthermore, we believe that our suppliers are mature enough to get the same rank, regardless of whether it is a self-assessment or an audit by the client," explained one respondent

The automaker calculates the rate of accuracy of deliveries by the ratio of the number of accurate deliveries runs by the total number of deliveries in a given period. Deemed to be correct are the deliveries which were carried out in strict accordance with the date and amount requested in the purchase order.

The data collected in the document analysis made it possible to execute stratified narratives. Graphic 1 shows the comparative rates of accuracy of delivery among suppliers that adopted the MMOG/LE recommendation and those that did not. The data represent initially the accuracy of delivery for the period April to September 2006, followed by the simple moving averages of the last six months, for the period between November 2006 and August 2007. The time gap between the first period presented and the second one was justified by the professional who set up the spreadsheet as a result of the company's operating practices.

It can be seen that the precision of delivery by suppliers who adopted the MMOG/LE recommendation gets better with each period, which does not happen with companies not using the tool. This may suggest that the adoption of the MMOG/LE recommendation is contributing to the improvement of logistics performance, although in part this is also influenced by the fact that suppliers who adopted the recommendation, presumably, are also those most aware of the importance of good logistics performance, considering that the automaker did not require, but only recommended its suppliers to use the tool. 
As one might observe, the half-year moving averages of the indicators of delivery of accuracy of suppliers raked in level A, in accordance with the MMOG/LE recommendation, are the highest, followed by medium-sized suppliers of level B and level C, which also expected. Based on this analysis, the company understands that the supplier's rank provides a good indication of what to expect of its logistics performance.

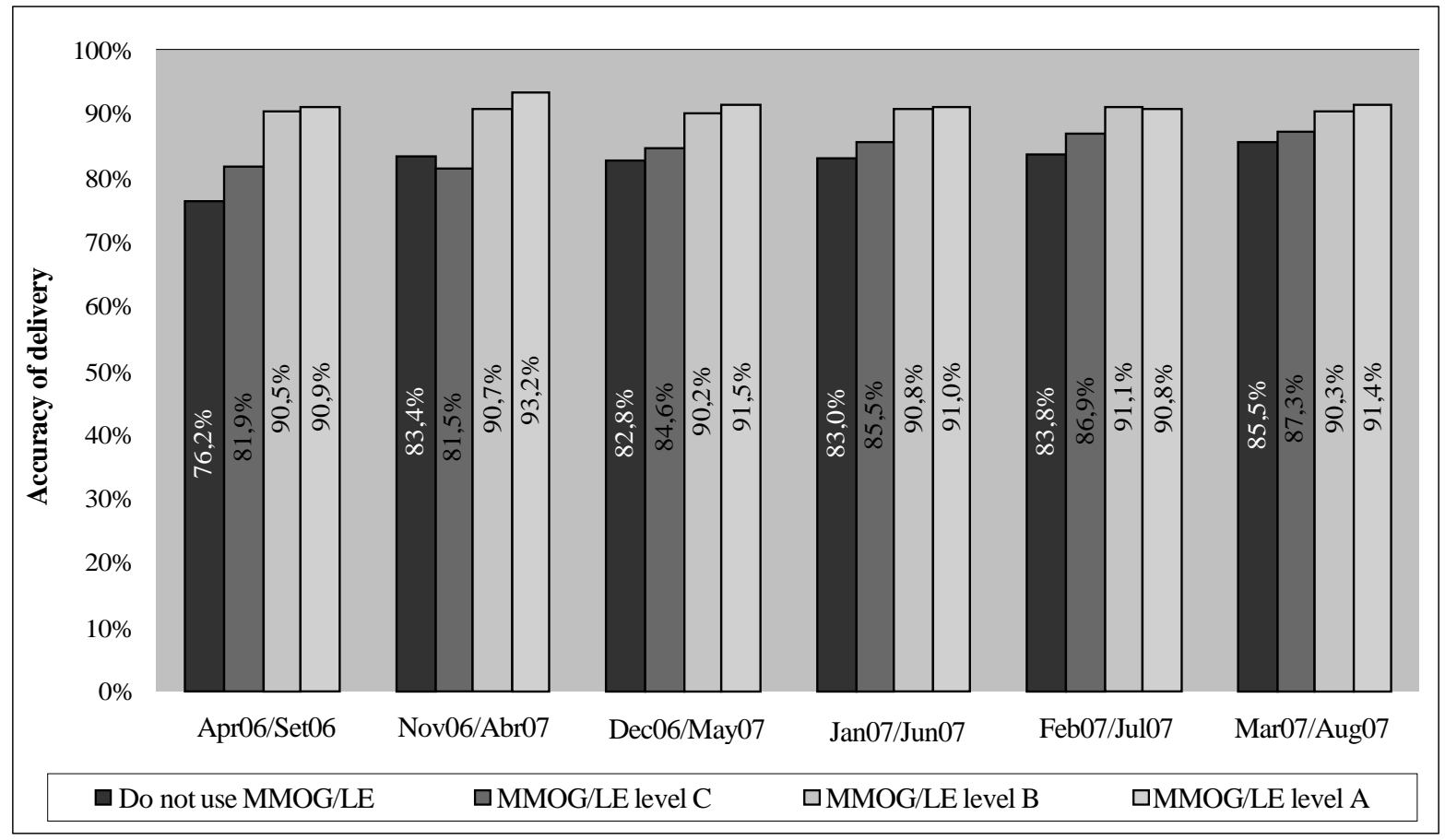

Graphic 1 - Comparative indices of accuracy of delivery according to the adoption (or not) of MMOG/LE Source: documentation from the automaker

With respect to the continuous improvement process, it is observed that the averages of suppliers in levels A and B remained almost constant over time, while the C-level suppliers showed considerable improvement. This can be attributed, in the view of respondents, to three factors: 1 - Class $\mathrm{C}$ suppliers have more features that need improvement, 2 - these vendors feel compelled (own determination) to present better indices and 3 - they requested by the automaker to improve their indices and, consequently, their performance.

The interviews with the professionals responsible for the automaker's logistics of receiving (inbound logistics) corroborate the data collected through the questionnaire applied to the suppliers and the documentary analysis about the effectiveness of the MMOG/LE recommendation. The professionals said that the tool is quite comprehensive and assesses the key logistics processes of the companies making up the supply chain. One said: "The MMOG/LE works like a check list of all logistics activities that may have some impact on the company's ability to meet its orders in the quantities and times agreed with the customer. Whoever cares to 
meet all its requirements, eliminates or at least reduces logistical risks. 'Murphy ' can attack the company, so it would better be prepared to react quickly and offer a solution to the problem. "MMOG/LE also contributes to the continuous improvement of logistics processes. For another respondent, "the proper use (seriously) the tool necessarily leads to improvements in logistics performance, namely the provision of better service at a lower cost."

The interview with the automaker's professionals also found the adoption of the MMOG/LE recommendation internally by the company itself. "Before we ask for the adoption by suppliers, we held our own self -assessment. After all, we are a part of the supply chain that also needs to be efficient in logistics processes, especially considering that represent a link of great added value and cost," said one respondent. Indeed, by being closer to the end customer and having control of the chain makes the automaker responsible for a good part not only of the value, but also of the cost, which is transferred to consumers. Moreover, the example is very important, especially considering that MMOG/LE is a recommendation, not a rule or determination. The voluntary nature of membership requires that the automaker assume a role of leadership and example, and not of imposition.

The respondents were unanimous in stating that: (1) greater knowledge of the MMOG/LE recommendation improves the view of the overall logistics of the supply chain, (2) it is important that all logistics professionals be aware of the recommendation, (3) there must be an alignment of the recommendation's requirements with the company's quality system, which helps to ensure its correct implementation, and (4) the recommendation contributed to make its users realize the need to electronically integrate with their suppliers in order to improve the quality of the logistics flow.

The respondents confirm the perception of their suppliers about the effective contribution of the MMOG/LE recommendation as a tool for the improvement of logistics performance, but made an important caveat: the automaker also uses other tools to improve the logistics performance of its suppliers, parallel to MMOG/LE. Thus, the improvement of logistics performance, evidenced in the analysis of documentary data, is the product of a set of actions, which has the MMOG/LE recommendation as focal point, but not isolated. Other factors also contribute to the advancement of accuracy of delivery.

\section{CONCLUSIONS}

Overall, the results of the survey applied to logistics professionals who were trained in the implementation of the tool were quite in line with the perception on the effectiveness of the automaker's MMOG/LE. Most of them agree that the MMOG/LE is a useful tool to measure the 
performance of logistics activities and thus for the detection of possible opportunities for improvement. Even those who have not yet implemented it at their companies say they will do soon.

Complementing the conducted survey with interviews with the automaker's professionals, it was possible to understand how they all realize the logistics assessment and the benefits that can be extracted from it.

The number of companies that have implemented a formal initiative of logistical evaluation, as allowed by MMOG/LE, is still small in Brazil, but the experience of the automotive industry can be spread to other industries, since they are all very dependent on the efficiency of their logistics processes to ensure their competitiveness in the market.

A limitation of this study is that, having been presented to the MMOG/LE recommendation by the researchers who had themselves conducted the training on its implementation in the companies, some survey participants may have felt inclined to respond not based on their perception, but on the answers they imagined researchers would like to see. Although the fact that two automaker employees collaborated in authoring this article is considered a key factor for the success of the research for having allowed a more comprehensive analysis of the company's internal and strategic documents without the need of having these documents handled directly the other two authors, from academia, this may also have contributed to some bias. After all, the company is a major supporter of the spread of MMOG/LE recommendation in the industry.

Further studies may address the understanding of the possibility of using this tool that was originally conceived to improve the reliability of the logistics processes in the automotive industry in other industrial environments, which can benefit from the achievements of this specific sector. In addition to that, as the adoption of MMOG/LE spreads in the automotive industry itself, it becomes possible to carry out studies involving a greater number of companies, increasing the statistical rigor and allowing for new levels of understanding of the phenomena being researched.

Finally, it is considered that the discussion in this paper about MMOG/LE has been important not only for the results obtained, but to stimulate debate about the need to measure logistics performance. The area has assumed a new magnitude of importance in organizational competitiveness and must therefore be measured and evaluated in order to be better managed and improved. 


\section{REFERENCES}

AIAG and Odette announce release of updated Global Materials Management Operations Guideline/Logistics Evaluation (MMOG/LE). July 24, 2006. Available at: http://www.aiag.org/staticcontent/press/releases/GENERAL/PR_MMOGLE06_final.pdf. Accessed on: 02/24/2008.

ALDER, Ken. A passion for precision. American Scientist. vol. 95, issue 3, p. 273-274. May/Jun, 2007.

BABBIE, Earl. Métodos de pesquisas de survey (Methods of survey research). Belo Horizonte: UFMG, 1999.

BALLOU, Ronald H. Gerenciamento da cadeia de suprimentos: planejamento, organização e logística empresarial (Supply chain management: planning, organization and logistics). 5. ed. Porto Alegre: Bookman, 2006.

BOWERSOX, Donald J.; CLOSS, David J.; COOPER, M. Bixby. Gestão logística de cadeias de suprimento (Logistics management of supply chains). Porto Alegre: Bookman, 2006.

BURKHALTER, Bettye B. The evolution of a continuous quality improvement process in a university setting: a working model for consideration. Total Quality Management. vol. 5, issue 4, p. 169-184. Jul., 1994.

COHEN, Max. Uso da informação na economia de informação: um estudo na indústria do estado de São Paulo (Use of information in the information economy: a study in the industry of São Paulo state). 2003. 133 p. Thesis (Doctorate in Business Administration) - Escola de Administração de Empresas de São Paulo, São Paulo, 2003.

COURÁ, Deise Portugal. A importância da logística no transporte de produtos frigorificados no Brasil: um estudo de caso na empresa Perdigão Agroindustrial (The importance of logistics in the transportation of refrigerated products in Brazil: a case study in the Perdigão Agroindustrial company). Thesis (Doctorate in Production Engineering). Universidade Federal de Santa Catarina, Florianópolis, 2002.

ERICSSON, K. Anders; PRIETULA, Michael J.; COKELY, Edward T. The making of an expert. Harvard Business Review, vol. 85, issue 7/8, p. 114-121. Jul/Aug, 2007.

FIGUEIREDO, Kleber; GOLDSMID, Ilana Kogan; ARKADER, Rebecca; HIJJAR, Maria Fernanda. Segmentação logística: um estudo na relação entre fornecedores e varejistas no Brasil (Logistics segmentation: a study about the relationship among suppliers and retailers in Brazil). Revista de Administração Contemporânea, v. 11, n. 4, Out./Dez. 2007: 11-31

GEBLER, David. Is Your Culture a Risk Factor? Business \& Society Review. vol. 111, issue 3, p. 337-362. Fall, 2006.

GRAEML, Alexandre Reis; CSILLAG, João Mário. Application of an e-mail survey using a Word form. In: Proceedings of the Seventeenth Annual Conference of POMS, Boston, MA. April 28 - May 1, 2006.

GHISI, Flávia Angeli; SILVA Andrea Lago da. Implantaçăo do efficient consumer response (ECR): um estudo multicaso com indústrias, atacadistas e varejistas (Implantation of ECR: a multicase study with manufacturers, wholesalers and retailers). Revista de Administração Contemporânea, v. 10, n. 3, Jul./Set. 2006: 111-132.

GUSTAFSSON, Claes; PERSSON, Andreas. Standardized implementation of Q1: Ford quality trustmark. (Masters thesis). Luleå University of Technology. Sweden AB, 
Gothenburg, 2007. Available at: http://epubl.luth.se/1402-1617/2007/082/LTU-EX-07082SE.pdf. Accessed on: 04/20/2008.

HA, Albert Y.; LI, Lode; NG, Shu-Ming. Price and delivery logistics competition in a supply chain. Management Science Informs. Vol. 49, No. 9, September 2003, p. 1139-1153.

HANDFIELD, Robert B.; PANNESI, Ronald T. An empirical study of delivery speed and reliability. International Journal of Operations \& Production Management. V. 12, No. 2. December, 1992, p. 58-72.

HARRINGTON, Lisa. Supplier logistics in the driver's seat. Inbound Logistics. July, 2005. Available at: http://www.inboundlogistics.com/articles/features/0705_feature04.shtml. Accessed on: 02/24/2008.

HIJJAR, Maria Fernanda; GERVÁSIO, Maria Helena; FIGUEIREDO, Kleber Fossatti. Mensuração de desempenho logístico e o modelo world class logistics. (Logistics performance measurement and the world-class logistics model) 2005. Available at: http://www.centrodelogistica.org/new/fs-busca.htm?fr-public.htm. Accessed on 02/21/2008.

INTERNET AUTOGUIDE. AIAG announces Global Materials Management Guidelines. InternetAutoguide.com. April 6, 2004. Available at: http://www.internetautoguide.com/ autonews/25-int/639/index.html. Accessed on: 02/24/2008.

JAWAB, Fouad; BOUAMI, Driss. Contribution à la mise au point d'une démarche d'audit logistique: Application à une entreprise marocaine (Contribution to the implementation of a process of logistics audit). 5eme Conference Internationale Conception et Production Intégrées. CPI'2007, 22-24, Octobre 2007. Available at: http://www.supmeca.fr/cpi2007/articles2007/CPI2007-106-Jawab.pdf. Acesso em 04/16/2008.

LI, Zhengping; KUMAR, Arun. Supply chain network scenario design and evaluation. International Journal of Logistics: research and applications. Vol. 8, No. 2, June 2005, p. 107-123.

MARTINS, Denise Maria; GONÇALVES, Marilson Alves. Eficácia dos indicadores de desempenho na cadeia de fornecimento automotivo.(Effectiveness of performance indicators in the automotive supply chain). In: Simpósio de Administração da Produção, Logística e Operações Industriais (SIMPOI). 7., 2004, São Paulo. Proceedings... São Paulo: FGVEAESP, October 2004.

MARUJO, Lino Guimarães. Uma nova abordagem organizacional para gestão da cadeia de suprimentos (A new organizational approach for supply chain management). Brazilian Business Review, vol. 3, n. 2. Jul./ Dez. 2006, p. 171-180.

MOLLENKOPF, Diane; DAPIRAN, G. Peter. The importance of developing logistics competencies: a study of Australian and New Zealand firms. International Journal of Logistics: research and applications. Vol. 8, No. 1, March 2005, p. 1-14.

NELSON, Bob. Strategic recognition. Leadership Excellence. vol. 24, issue 2. Feb., 2007.

NUGENT, Patrick. Add value with measurement. Quality. vol. 46, issue 9, p. 30-32, Sep., 2007.

ODETTE; AIAG. Global Materials Management Operations Guideline/Logistics Evaluation. Odette's Global document downloads. 2006. Disponível em: http://www.odette.org/html/ gldownloads.htm. Accessed on: 03/01/2008.

ONICA, Terry. Progress toward a perfect lean market. Action Line, Sep/Oct, 2006. 
PARRY, Glenn; GRAVES, Andrew; JAMES-MOORE, Mike. The threat to core competence posed by developing closer supply chain relationships. International Journal of Logistics: research and applications. Vol. 9, No. 3, September 2006, p. 295-305.

QUALITY PROGRESS. AIAG Announces Global Materials Management Guidelines. Quality Progress. June, 2004, p. 21. Available at:

http://www.asq.org/pub/qualityprogress/past/0604/qp0604keepingcurrent.pdf. Acessed on: 04/20/2008.

SCORNAVACCA JR., Eusébio; BECKER, João Luiz; ANDRASCHKO, Rafael. E-survey: concepção e implementação de um sistema de survey por Internet (.E- survey: design and implementation of a survey by the Internet). In: Encontro Nacional da Associação Nacional de Programas de Pós-Graduação e Pesquisa em Administração (Enanpad). 25., 2001, Campinas. Proceedings... Rio de Janeiro: ANPAD, 16 to 19 September 2001.

TABOADA, Carlos. Logística: o diferencial da empresa competitiva (Logistics: the company's competitive differential). Revista FAE Business, n. 2, Jun. 2002. p. 4-8.

VIEIRA, B. L. A.; VIANA, D. A.; ECHEVESTE, S. Comércio eletrônico via Internet: uma abordagem exploratória (E-commerce via the Internet: an exploratory approach). In: Encontro Nacional da Associação Nacional de Programas de Pós-Graduação e Pesquisa em Administração (Enanpad). 22., 1998. Foz do Iguaçu. Proceedings... Rio de Janeiro: ANPAD, September, 1998.

WITT, Clyde E. Guidelines developed by the auto industry offer a roadmap for enhanced material handling, ease the identification performance gaps in the supply chain, and establish long-needed performance benchmarks. Material Handling Management. vol. 60, issue 5, p. 20-29, May 2005.

YAN, Jianyuan; CHAUDHRY, Peggy E.; CHAUDHRY, Sohail S. A model of a decision support system based on case-based reasoning for third-party logistics evaluation. Expert Systems. vol. 20, issue 4, p. 196-207. Sep., 2003.

ZOLLER, K. Differentiating in-stock service by customer value. International Journal of Logistics: research and applications. Vol. 9, No. 2, June 2006, p. 95-110.

\section{Notes}

\footnotetext{
${ }^{1}$ This expression is sometimes attributed to Peter Drucker (Nelson, 2007; Gebler, 2006), sometimes to the quality gurus BURKHALTER, 1994), or to countless other authors. Some attribute it to the most remote origins. Lord Kelvin in the nineteenth century would have used the phrase ERICSSON et al., 2007), warning that "when you can measure what you're talking about and express it in numbers, you know something about it, but when you cannot measure it, when you cannot express the argument in numbers, the existing knowledge is of a poor and unsatisfactory kind " (ALDER, 2007; NUGENT, 2007). Galileo Galilei would have been a source of inspiration to the phrase, as he recommend, still in the fourteenth century: "tell me what is countable, measure what is measurable. What is not measurable, make measurable" (NUGENT, 2007).

${ }^{2}$ The U.S. automaker Ford had adopted the Q1 logistics certification system, the French Renault used EAQL, which was also the case at Sweden's Volvo. All of them have already migrated or are migrating to MMOG/LE. German carmaker Volkswagen has used the VBA (Odette Logistic Evaluation) system to assess their logistics suppliers. Peugeot and Citroen in France, continue with the EAQL certification, as explained by one of the professionals interviewed by the authors of this paper.

${ }^{3}$ In addition to the critical processes (F3), MMOG/LE includes other processes less impacting on the chain, in case they present some deficiency, but still they have to be controlled in order to increase the quality of logistic flow. Those processes are named F2 (meanly impacting) and F1 (less important).
} 